\title{
Synthesis and biological evaluation of PEGylated CuO Nanoparticles
}

\author{
K. Giannousi, ${ }^{\text {a }}$ E. Hatzivassiliou, ${ }^{\text {b }}$ S. Mourdikoudis,${ }^{c}$ G. Vourlias, ${ }^{\text {d }}$ A. Pantazaki ${ }^{\mathrm{e}}$ and \\ C. Dendrinou-Samara ${ }^{\mathrm{a}^{*}}$
}

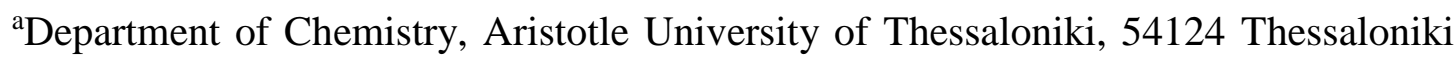

Greece e-mail: samkat@ chem.auth.gr

${ }^{\mathrm{b} S c h o o l}$ of Medicine, Aristotle University of Thessaloniki Medical School, Thessaloniki, Greece

'Departamento de Quimica Fisica, Universidade de Vigo, 36310 Vigo, Spain

${ }^{\mathrm{d}}$ Department of Physics, Aristotle University of Thessaloniki, 54124 Thessaloniki

${ }^{\mathrm{e}}$ Laboratory of Biochemistry, Department of Chemistry, Aristotle University of Thessaloniki, 54124 Thessaloniki

\begin{abstract}
There is a growing field of research into the physicochemical properties of metal oxide nanoparticles (NPs) and their potential use against tumor formation, development and progression. Coated NPs with biocompatible surfactants can be incorporated into the natural metabolic pathway of the body and specifically favor delivery to the targeted cancerous cells versus normal cells. Polyethylene glycol (PEG) is an FDA approved, biocompatible synthetic polymer and PEGylated NPs are regarded as "stealth" nanoparticles, which are not recognized by the immune system. Herein, PEGylated cupric oxide nanoparticles (CuO NPs) with either PEG 1000 or PEG 8000 were hydrothermally prepared upon properly adjusting the reaction conditions. Depending on the reaction time $\mathrm{CuO}$ NPs in the range of core sizes 11-20 nm were formed, while hydrodynamic sizes substantially varied (330-1120 nm) with improved colloidal stability in PBS. The anticancer activity of the NPs was evaluated on human cervical carcinoma HeLa cells by using human immortalized embryonic kidney 293 FT cells as a control. Viability assays (3-(4,5-dimethylthiazol-2-yl)-2,5-diphenyltetrazolium bromide, MTT) revealed that $\mathrm{CuO}$ NPs could selectively reduce viability of tumor cells ( $\mathrm{IC}_{50}$ values $11.91-25.78 \mu \mathrm{g} / \mathrm{mL}$ ). Reactive oxygen species (ROS) production, cell
\end{abstract}


membrane damage and apoptotic DNA laddering were also evident by nitroblue tetrazolium (NBT) reduction, lactate dehydrogenase (LDH) release assays and DNA electrophoresis, respectively. $\mathrm{CuO}$ NPs strongly inhibited lipoxygenase (LOX) enzymatic activity with $\mathrm{IC}_{50}$ values $4-5.9 \mu \mathrm{g} / \mathrm{mL}$, highlighting in that manner their antiinflammatory activity.

Keywords: Copper oxide nanoparticles, Anticancer activity, Anti-inflammatory activity

\section{Introduction}

Nanotechnology plays an important role in therapies of the future as "nanomedicine", by allowing to decrease the required efficient dose as well as to increase the therapeutic indices and safety profiles of new therapeutics. ${ }^{1}$ In so, new types of anticancer agents are being explored that have the potential to overcome problems with the existing anticancer therapies while focusing on better selectivity, efficacy in lower doses and decrease of their side effects. ${ }^{2}$ Their anticancer activity is believed to be mediated either directly by their antioxidant action or indirectly through heating. Among them, metal oxide nanoparticles (NPs) are under intense investigation mainly from a toxicity point of view, due to the detrimental effects reported on cells. ${ }^{3,4}$ Those NPs have the ability to perturb the cell membranes, to degrade the DNA and to react with proteins either directly or indirectly by producing reactive oxygen species (ROS). Meanwhile, another aspect is to utilize these adverse effects in order to induce death of tumor cells. ${ }^{5}$ For example, by comparing "naked" commercial transition metal oxide NPs, the chemical composition was found to be the crucial factor affecting their ability to kill cells with the rank of cytotoxicity being $\mathrm{CeO}_{2}<\mathrm{Al}_{2} \mathrm{O}_{3}<\mathrm{SiO}_{2}<\mathrm{ZnO}<\mathrm{CuO}^{6}$ Their activity was mediated by an increase in intracellular ROS. 
Due to the established antimicrobial activity of copper, ${ }^{7}$ copper oxide NPs have been also evaluated as antimicrobial agents by us ${ }^{8,9,10}$ and others. ${ }^{11,12}$ In that vein, $\mathrm{Cu}_{2} \mathrm{O}$ NPs of $16 \mathrm{~nm}$ and $12 \mathrm{~nm}$ exhibit $\mathrm{IC}_{50}$ values of $2.13 \mu \mathrm{g} / \mathrm{mL}$ and $3.7 \mu \mathrm{g} / \mathrm{mL}$ against Bacillus cereus and B. subtilis. ${ }^{9}$ "Naked" CuO NPs with particle size $20 \pm 1.24 \mathrm{~nm}$ were more effective in regard of bacterial growth inhibition towards Staphylococcus aureus, Escherichia coli, B. subtilis and Pseudomonas aeruginosa by using both broth dilution and Kirby Bauer disc diffusion method. By the disc diffusion method the maximum zone of inhibition (ZOI) was recorded against B. subtilis $(24 \mathrm{~mm})$ and S. aureus $(22$ $\mathrm{mm}$ ), while the lowest minimum inhibitory concentration (MIC) value was recorded in case of E. coli $(20 \mu \mathrm{g} / \mathrm{mL}) .{ }^{11}$ Concerning their mechanism of action, although there is still lack of sufficient knowledge, ${ }^{13}$ different activity pathways are suggested for the two copper oxides (I and II), with the involvement of ROS mainly in case of CuO NPs. ${ }^{14}$ There are limited studies evaluating the anticancer activity of CuO NPs. Towards this direction $\mathrm{CuO}$ NPs of $22 \mathrm{~nm}$ size were tested in human hepatocellular carcinoma cells (HepG2) and the results showed that cell viability decreased gradually to $28 \%$ when cells were exposed to higher concentrations of $\mathrm{CuO} \mathrm{NPs} .{ }^{15}$ In another study, CuO NPs $(\sim 30 \mathrm{~nm})$ were applied in human breast cancer cell line MCF7 to correlate autophagy with apoptosis and the results demonstrated that the NPs induce in vitro growth inhibition and autophagy in the cells. ${ }^{16}$ Despite the fact that in both studies increase in the ROS production is involved, ROS and cancer are associated in a paradoxical manner; ROS and oxidative stress induce carcinogenesis, but higher increase of ROS levels enhance cell death. ${ }^{17}$ It has to be mentioned that the absence of any protecting coating in the above studies is a drawback that affects the selectivity of the respective NPs. 
Polyethylene glycolation (PEGylation) offers stealth characteristics, which referred also as the enhanced permeation and retention effect (EPR). As a result of the EPR effect, PEGylated NPs can penetrate through the leaky vasculature of the tumor cells, whereas the normal tissue has a tight vasculature. ${ }^{18,19}$ Moreover, PEGylated NPs are able to avoid the non-specific interactions with opsonic proteins and uptake by the reticulo-endothelial system (RES) and this is very crucial in case of in vivo applications. However, $\mathrm{CuO}$ nanoparticles coated with polyethylene glycols are scarcely reported in the literature. Submicron $\mathrm{CuO}$ nanomaterials were prepared through hydrothermal method in the presence of very low concentrations $(2 \mu \mathrm{M})$ of PEG 20000 and found to exhibit higher antibacterial activity than $\mathrm{CuO}$ nanomaterials prepared through coprecipitation routes, mainly through ROS production and lipid peroxidation. ${ }^{20}$

Herein, we chose to prepare PEGylated CuO NPs of different sizes with stealth characteristics to investigate their anticancer performance. Towards this goal, CuO NPs of different sizes were hydrothermally synthesized in the presence of either polyethylene glycol 1000 or polyethylene glycol 8000 upon adjusting properly the reaction temperature and time, since dissolution and crystallization processes take place. Their effects were evaluated on human cervical carcinoma HeLa cells while human immortalized embryonic kidney 293 FT cells were used as a control. HeLa cells were selected since are one of the best characterized human cell lines and one of the most popular cellular models in science and industry. Apart from the ROS production, which was measured by the nitroblue tetrazolium (NBT) reduction, cell membrane damage was also investigated by testing for lactate dehydrogenase (LDH) release. The DNA from the cells was isolated and studied for apoptotic fragmentation signs. Moreover, based on the close relationship between cancer and inflammation, ${ }^{21}$ the anti- 
inflammatory activity of $\mathrm{CuO}$ NPs was also studied in vitro by evaluating the inhibition of the enzymatic activity of lipoxygenase (LOX).

\section{Experimental}

\section{Materials}

Copper(II) nitrate trihydrate (Merck, $\geq 99.5 \%, \quad \mathrm{M}=241.60 \mathrm{~g} / \mathrm{mol}$, $\mathrm{Cu}\left(\mathrm{NO}_{3}\right)_{2} \cdot 3 \mathrm{H}_{2} \mathrm{O}$ ), hydrazine hydrate (Merck, $\sim 100 \%, \mathrm{M}=50.06 \mathrm{~g} / \mathrm{mol}, \mathrm{N}_{2} \mathrm{H}_{4} \cdot \mathrm{H}_{2} \mathrm{O}$ ), polyethylene glycol 8000 (Merck, M = $8000 \mathrm{~g} / \mathrm{mol}$ ), polyethylene glycol 1000 (Merck, $\mathrm{M}=950 \mathrm{~g} / \mathrm{mol}$ ) were of analytical grade and were used without any further purification. Tissue culture coverslips (13 mm) were bought from Sarstedt. Microscope slides were provided from Superfrost (O. Kindler GmbH). Culture medium DMEM (Dulbecco's modified Eagle's medium with L-glutamine), fetal bovine serum (FBS), antibioticantimycotic, and phosphate buffered saline (PBS, $\mathrm{pH}=7.2$ ) were obtained by E.U Gibco BRL. Trypsin + EDTA and 3-(4,5-dimethylthiazol-2-yl)-2,5diphenyltetrazolium bromide (MTT powder) were purchased from Invitrogen. All reagents were used without any further purification.

Preparation of $\mathrm{CuO}$ NPs. All the synthetic routes followed the same procedure of hydrothermal synthesis into a $23 \mathrm{~mL}$ Teflon-lined stainless-steel autoclave. The surfactants that have been used were either PEG 1000 or PEG 8000. Experimental results are summarized in Table 2 . The reaction time and temperature were varied from 6 to 12 hours and from 150 to $160{ }^{\circ} \mathrm{C}$, respectively, while the ratio of precursor to reducing agent (1:1) as well as precursor to surfactant ratio (1:1) were kept the same in all the experiments. 
In a typical synthesis (e.g. Sample S1), $2 \mathrm{mmol}(0.5 \mathrm{~g}) \mathrm{Cu}\left(\mathrm{NO}_{3}\right)_{2} \cdot 3 \mathrm{H}_{2} \mathrm{O}$ were dissolved in $10 \mathrm{ml}$ deionized water to obtain a blue solution. Then $2 \mathrm{mmol}(0.103 \mathrm{~g})$ $\mathrm{N}_{2} \mathrm{H}_{4} \cdot \mathrm{H}_{2} \mathrm{O}$ were added dropwise to the solution under vigorous stirring and the color changed from blue to yellow, indicating the reduction of $\mathrm{Cu}^{2+}$. A solution of $2 \mathrm{mmol}$ (2 g) PEG 1000 was added and the resulting mixture was stirred thoroughly and then transferred into the autoclave, while the crystallization was carried out under autogenous pressure. Afterwards, the autoclave was cooled gradually to room temperature and after centrifugation at $5000 \mathrm{rpm}$ for $20 \mathrm{~min}$, the supernatant liquids were discarded and the precipitates were obtained and washed with ethanol, at least three times, in order to remove the excess of ligands and unreacted agents.

\section{NPs Characterization}

X-Ray powder diffraction graphs (XRD) were recorded at Bragg-Brentano (BB) geometry using a two-cycles Rigaku Ultima+ powder X-ray diffractometer with a $\mathrm{Cu}$ Ka radiation operating at $40 \mathrm{kV} / 30 \mathrm{~mA}$. Transmission Electron Microscopy (TEM) images were obtained with a JEOL $100 \mathrm{CX}$ microscope, operating at an acceleration voltage of $100 \mathrm{kV}$. For TEM observations we have used suspensions of the nanoparticles deposited onto carbon-coated copper grids. The dynamic light scattering (DLS) and zeta potential measurements were performed with a Malvern Zetasizer instrument. Infrared spectra $\left(280-4000 \mathrm{~cm}^{-1}\right)$ were recorded on a Nicolet FTIR 6700 spectrometer with samples prepared as $\mathrm{KBr}$ pellets. Thermogravimetric analysis (TGA) was performed using SETA-RAM SetSys-1200 and carried out in the range from room temperature to $900{ }^{\circ} \mathrm{C}$ at a heating rate of $10{ }^{\circ} \mathrm{C} \min ^{-1}$ under $\mathrm{N}_{2}$ atmosphere. The ionic release was determined by flame atomic absorption spectrophotometry (FAAS) using a Perkin Elmer instrument, model AAnalyst 800 after $24 \mathrm{~h}$.

\section{Biological Studies}




\section{Cell culture}

HeLa and 293 FT cell lines were cultured in DMEM supplemented with 10\% FBS and the antibiotics penicillin and streptomycin. The cell lines were maintained in culture at $37{ }^{\circ} \mathrm{C}$, in $5 \% \mathrm{CO}_{2}$, in a humidified incubator, using standard aseptic techniques and cell growth was monitored by determining the cell number with the use of a Neubauer hemocytometer.

\section{Viability assay (MTT)}

Cells were seeded in 96-well plates at a density of $5 \times 10^{3}$ cells per well and incubated for $24 \mathrm{~h}$ to allow cell growth. Titration experiments were performed in order to evaluate the cell viability upon increasing concentrations ranging from $5-100 \mu \mathrm{g} \cdot \mathrm{mL}^{-1}$ of the NPs. Towards this purpose the cells were further incubated with the respective NPs suspensions for $24 \mathrm{~h}$. Cells that were not exposed to NPs served as control. At this point cell growth was measured by monitoring the conversion of 3-(4,5-dimethyl-2thiazolyl)-2,5-diphenyl-2H-tetrazolium bromide (MTT) to formazan, since the reduction of MTT is catalyzed by mitochondrial dehydrogenase enzyme. Briefly, $24 \mathrm{~h}$ after the addition of the NPs to the cells the medium was removed from each well and replaced with $100 \mu \mathrm{L}$ fresh medium containing $10 \mu \mathrm{L}$ MTT $20 \mathrm{mM}\left(5 \mathrm{mg} \cdot \mathrm{mL}^{-1}\right)$ per well. After another incubation for $4 \mathrm{~h}$ at $37{ }^{\circ} \mathrm{C}$ (until the development of the purple colored formazan product) $100 \mu \mathrm{L}$ of Sodium Dodecyl Sulfate (SDS) 10\%-HCl 0.01 $\mathrm{M}$ were added to the cells and incubated in the dark for $15 \mathrm{~min}$. The absorbance was measured at dual wavelength $570 \mathrm{~nm}$ and $630 \mathrm{~nm}$ using a Bio-Tek Microplate AutoReader 311SX (BIO-TEK Instruments INC, USA). Each sample was triplicated. For statistical analysis, Student's t-test was performed to evaluate the difference between samples and control, while differences among the samples and the cell lines 
were analyzed by One Way Analysis of Variance (ANOVA) followed by Tukey test. Statistical significance was considered at $\mathrm{p}<0.05$.

\section{Lactate dehydrogenase assay (LDH)}

Lactate dehydrogenase leakage (LDH), which is a measure of cytotoxicity on the basis of membrane integrity damage, was determined using a commercial LDH Kit (Biochain) according to the manufacturer's protocols. This procedure is based on the method developed by Ulmer et al., ${ }^{22}$ optimized for greater sensitivity and linearity. HeLa cells were seeded in 96-well culture plate at a density of $2 \times 10^{4} / \mathrm{mL}$ in DMEM supplemented with antibiotics penicillin and streptomycin but without FBS in order to avoid the background of the serum. After 16 hours of incubation at $37{ }^{\circ} \mathrm{C}$ in a humidified atmosphere containing 5\% $\mathrm{CO}_{2}, \mathrm{CuO}$ NPs (samples $\mathrm{S} 1-\mathrm{S} 5$ ) at the concentrations of $5,10,25,50$ and $100 \mu \mathrm{g} \mathrm{ml}^{-1}$ were added. The cells with the NPs were incubated for $24 \mathrm{~h}$ while non-exposed cells were used as negative controls. Then, the cell culture medium was collected for LDH measurement. An aliquot of $100 \mu \mathrm{l}$ cell medium was used for LDH activity analysis and the absorbance at $490 \mathrm{~nm}$ was measured using a Bio-Tek Microplate AutoReader 311SX (BIO-TEK Instruments INC, USA). Each sample was triplicated. For statistical analysis, Student's t-test was performed. Statistical significance was considered at $\mathrm{p}<0.05$.

\section{Nitroblue tetrazolium assay (NBT)}

The reactive oxygen species (ROS), which are created intracellularly as result of treatment of HeLa cells with $\mathrm{CuO}$ NPs, were measured by the nitroblue tetrazolium (NBT) reduction using the protocol described by Becerra et $a l .{ }^{23}$ For this purpose 100 $\mu \mathrm{L}$ cell suspension (cell culture was incubated overnight) in DMEM was incubated with respective $\mathrm{CuO}$ NPs (samples S1-S5) and $500 \mu \mathrm{L}$ of $1 \mathrm{mg} / \mathrm{mL}$ NBT for $1 \mathrm{~h}$ at $37{ }^{\circ} \mathrm{C}$. 
Then, $100 \mu \mathrm{L}$ of $0.1 \mathrm{M} \mathrm{HCl}$ was added and the tubes were centrifuged at $1500 \mathrm{~g}$ for 10 min. The pellets were treated with $600 \mu \mathrm{L}$ DMSO to extract the reduced NBT. Finally, $500 \mu \mathrm{L}$ DMEM was added and formazan blue obtained from cells was measured as optical density (OD) at $575 \mathrm{~nm}$ (intracellular ROS).

\section{Genomic DNA isolation from HeLa cells exposed to CuO NPs}

Cells were seeded in 96-well plates at a density of $5 \times 10^{3}$ cells per well and incubated for $24 \mathrm{~h}$ to allow cell attachment. After the addition of 10 and $100 \mu \mathrm{g} \cdot \mathrm{mL}^{-1}$ of the $\mathrm{CuO}$ NPs, the cells were further incubated with the NPs suspensions for $24 \mathrm{~h}$. Then, the cultures were washed three times with PBS and were pelleted in a micro centrifuge tube. The cell pellets were resuspended in $200 \mu \mathrm{l}$ of lysis buffer [ $2 \%$ Triton X-100, $1 \%$ SDS, $100 \mathrm{mM} \mathrm{NaCl}, 10 \mathrm{mM}$ Tris- $\mathrm{HCl}$ (pH 8.0), $1 \mathrm{mM}$ EDTA (pH 8.0)]. The tubes were placed on ice for two minutes (until they were completely frozen), then immersed in a $95{ }^{\circ} \mathrm{C}$ water bath for 1 minute to thaw quickly and finally were vortexed vigorously for 30 seconds. The process was repeated twice. ${ }^{24}$ After centrifugation for 5 min at 1600 $\mathrm{x} g$ the supernatants are collected, brought to $1 \%$ SDS and treated for $2 \mathrm{~h}$ with RNase A (final concentration $5 \mu \mathrm{g} / \mathrm{mL}$ ) at $56{ }^{\circ} \mathrm{C}$ followed by digestion with proteinase $\mathrm{K}$ (final concentration $2.5 \mu \mathrm{g} / \mathrm{mL}$ ) for at least $2 \mathrm{~h}$ at $37^{\circ} \mathrm{C}$. After addition of $1 / 2$ volume $10 \mathrm{M}$ ammonium acetate, the DNA is precipitated with 2.5 volume ethanol. ${ }^{25}$

\section{DNA binding/cleavage experiment in agarose gel electrophoresis}

The DNA binding/cleavage efficiency of the NPs was measured by determining their ability to alter the mobility of the isolated DNA and/or to cause degradation. Upon the addition of $5 \mu \mathrm{L}$ loading buffer consisting of $0.25 \% \mathrm{w} / \mathrm{v}$ bromophenol blue and $30 \%$ v/v glycerol in water, the products resulting from interactions of the NPs with DNA were separated by electrophoresis on agarose gels $(1 \% \mathrm{w} / \mathrm{v})$, which contained $1 \mu \mathrm{g} / \mathrm{mL}$ 
ethidium bromide in $40 \cdot 10^{-3} \mathrm{M}$ Tris-acetate, $\mathrm{pH} 7.5,2 \cdot 10^{-2} \mathrm{M}$ sodium acetate, $2 \cdot 10^{-3}$ $\mathrm{M} \mathrm{Na} \mathrm{N}_{2} \mathrm{EDTA}$, at $5 \mathrm{~V} \cdot \mathrm{cm}^{-1}$. Agarose gel electrophoresis was performed in a horizontal gel apparatus (Mini-SubTM DNA Cell, BioRad) for about $1 \mathrm{~h}$. The gels were visualized after staining with the fluorescence intercalated dye ethidium bromide under a UV illuminator.

\section{Evaluation of lipoxygenase activity}

The reaction mixture contained (final concentration) the CuO NPs (samples S1-S5), dissolved in water at concentrations of $2-10 \mu \mathrm{g} \cdot \mathrm{mL}^{-1}$, or the solvent (control), soybean lipoxygenase, dissolved in $0.9 \% \mathrm{NaCl}$ solution $\left(250 \mathrm{u}^{\mathrm{mL}} \mathrm{L}^{-1}\right.$ final concentration $)$ and sodium linoleate $(100 \mu \mathrm{M})$, in Tris- $\mathrm{HCl}$ buffer, $\mathrm{pH}$ 9.0. The reaction was monitored for $9 \mathrm{~min}$ at $28{ }^{\circ} \mathrm{C}$, by recording the absorbance of a conjugated diene structure at $234 \mathrm{~nm}$, due to the formation of 13-hydroperoxy-linoleic acid. The performance of the assay was checked using naproxen as a reference.

\section{Results and discussion}

\section{Synthesis and characterization of CuO NPs}

For the synthesis of $\mathrm{CuO}$ NPs a simple hydrothermal procedure into a Teflonlined stainless-steel autoclave was employed. Generally, hydrothermal synthesis of $\mathrm{CuO}$ NPs are governed both by thermodynamic and kinetic growth. The depicted experimental conditions were based on our previous results as the composition of $\mathrm{Cu}$ based NPs is strongly influenced by specific reaction parameters. ${ }^{8-10}$ Solution $\mathrm{pH}$ and 
temperature are the factors which affect the mixed potential, and thus the most stable chemical species can be changed by the $\mathrm{pH}$ and temperature. ${ }^{26,27}$ The stabilization of $\mathrm{CuO}$ NPs occurs in the temperature range of 150 to $160{ }^{\circ} \mathrm{C}$ in reaction time longer than 4 hours. By differentiating both the molecular weight (MW) of the surfactant and the reaction times, NPs in a range of primary sizes can be isolated, in accordance with PEG MW that has a strong influence on the viscosity of the solution. PEG with high MW (>6000) decrease the dispersion of the metal salt, as behaves like a linear hydroxyl polymer, which is very hydrophilic in nature. It restricts the migration of the metal ions and thus affects the size of the nanoparticles. ${ }^{28}$ It has to be mentioned that crystallinity of the final product will not be affected much when using different MW PEG. ${ }^{20}$ The reductive ability of polyethylene glycols is an effective way to adjust the redox reactions and the crystallization of copper oxides, while the size of the NPs strongly depends on time as the competition between Ostwald ripening and dissolution took place. ${ }^{29}$ Meanwhile, the $\mathrm{pH}$ of the reaction suspension has been initially adjusted at 298 $\mathrm{K}$ by using the same amount of reducing agent, hydrazine, in all the experiments. In that manner, five different samples of $\mathrm{CuO}$ NPs (S1-S5) were prepared by differentiating the reaction time and in the presence of the biocompatible surfactants polyethylene glycol 1000 and polyethylene glycol 8000. The reaction time and temperature were varied from 6 to 12 hours and from 150 to $160{ }^{\circ} \mathrm{C}$, respectively concerning that the long chain polyols exhibit weaker reductive ability than those of lower molecular weight, in respect of PEG 8000 and PEG 1000. Table 1 summarizes the experimental procedures and the main characteristics of the resulted NPs.

The phase composition and crystalline structure were determined via XRD measurements (Figure 1). All samples exhibited the monoclinic structure of $\mathrm{CuO}$ (ICDD, JCPDS card No. 80-1916). The average crystalline sizes of the NPs of all the 
samples were determined by measuring the full width at half-maximum (FWHM) of the most intense peaks and using the Scherrer equation (Table 1). Lattice parameters were also calculated by using MDI's Jade software and the corresponding values presented in Table 1, are in good agreement with the standard values reported by the JCPDS card No 80-1916, demonstrating the high crystallinity of the samples.

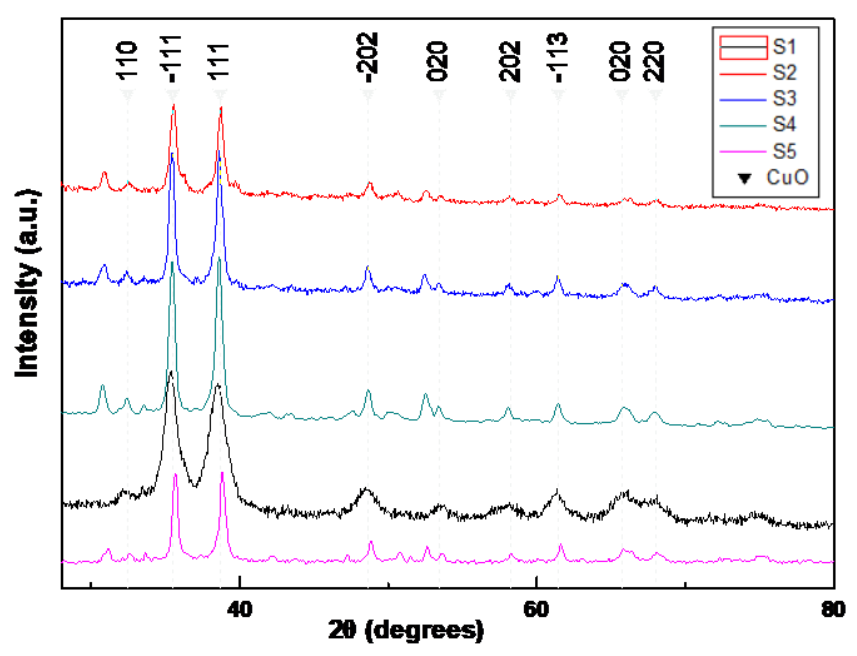

Figure 1. XRD patterns of samples S1-S5. Vertical lines denote expected diffraction peak positions for $\mathrm{CuO}$.

TEM micrographs of sample S1 prepared in the presence of PEG 1000 and samples S2, S3 and S4 in PEG 8000 are illustrated in Figure 2. Both polyethylene glycols resulted in the formation of NPs of similar morphology. It has to be mentioned that $\mathrm{CuO}$ NPs present different morphology when they are prepared upon oxidation of copper nanoparticles. In our previous study, Cu NPs coated with PEG 8000 were oxidized over time to leaf-like structured $\mathrm{CuO}$ NPs, ${ }^{9}$ while the same shape has been reported also for $\mathrm{CuO}$ nanocrystals prepared either by oxidizing copper NPs in hexadecyl trimethyl ammonium bromide solution $(\mathrm{CTAB})^{30}$ or through pulsed copper wire explosion system in distilled water. ${ }^{31}$ 

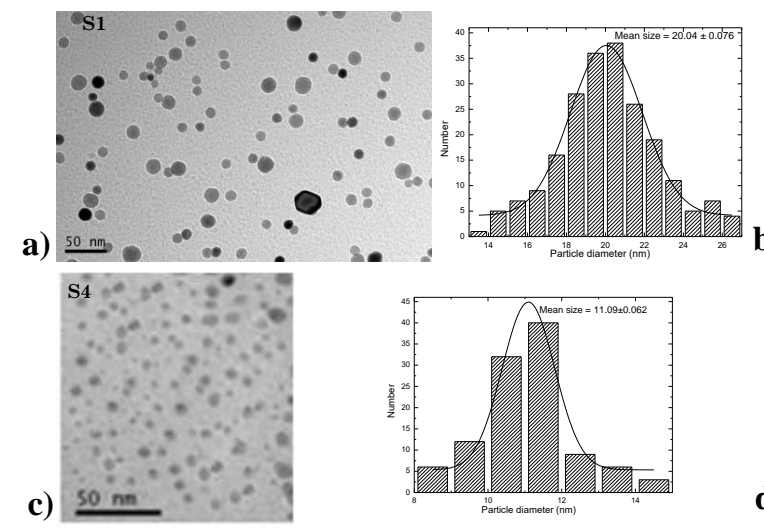

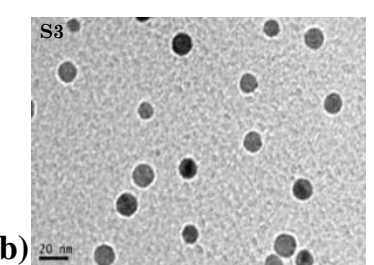

b) 20
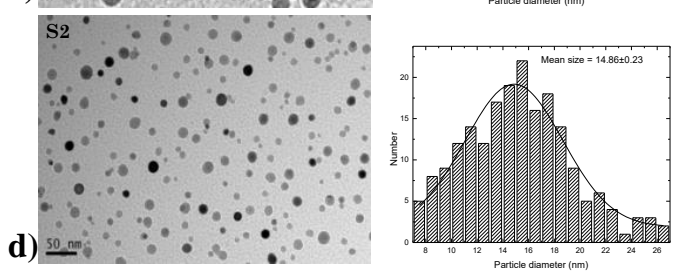

Figure 2. TEM images and size distributions of samples S1 (a), S3 (b), S4 (c) and S2 (d).

The as prepared NPs are readily dispersible in aqueous solution due to the in situ hydrophilic surface coating. The colloidal stability of the CuO NPs is an important issue relating to their biological properties. Thus, the samples were dispersed in phosphate buffered saline (PBS) after the synthesis without any further modification and by the means of DLS measurements their hydrodynamic size was determined and presented in Table 1. The free hydroxyl groups extending from the surface of the nanoparticles enable the electrostatic stabilization of the NPs with the steric exclusion forces leading to their stabilization in PBS. PEGylation refers to a typical state of steric exclusion where based on the amount of PEG on the surface of the nanoparticles provides a steric barrier. ${ }^{32}$ The hydrodynamic size for samples S1 and S5 coated with PEG 1000 was determined as $998 \mathrm{~nm}$ and $1120 \mathrm{~nm}$ respectively, while samples S2, S3 and S4 coated with PEG 8000 displayed much lower values (330-389 nm). The polydispersity index was found in the range of $0.2-0.4$ and the zeta potential measurements revealed the slightly negative charge on the surface of the NPs dispersed in PBS (-13 mV to $-1.03 \mathrm{mV})$. The lower molecular weight of PEG 1000 in combination with the lower amount of surfactant on the surface of the NPs (as indicated by the TGA 
curves, Fig. 4) allows for aggregation. On the contrary, in case of PEG 8000, the size of the NPs is more indicative of clustering and network formation.

The presence of the surfactants has been testified by FT-IR spectroscopy. FTIR spectra of the samples S1, S5 and S2-S4 with the corresponding patterns of PEG 1000 and PEG 8000 are given in Figure 3(a) and 3(b) respectively for comparison reasons. In all samples medium peaks at about $2920 \mathrm{~cm}^{-1}$ and $2860 \mathrm{~cm}^{-1}$ are assigned to the asymmetric $\left(v_{\text {as }}\right)$ and symmetric $\left(v_{\mathrm{s}}\right)$ stretching vibrations of methylene $\left(-\mathrm{CH}_{2}\right)$ groups, common in both surfactant molecules. The broad peak around $1643 \mathrm{~cm}^{-1}$ is ascribed to the hydrogen bonds, formed from the hydroxide groups while the C-O-C ether stretch band at $1106 \mathrm{~cm}^{-1}$ is indicative of the presence of polyethylene glycols. The peaks located at the region $500-540 \mathrm{~cm}^{-1}$ are assigned to $\mathrm{CuO}$ metal - oxygen bond, being recorded in all samples and further verifying the composition and are in agreement with the absence of $\mathrm{Cu}_{2} \mathrm{O}$. In its crystal lattice $\mathrm{CuO}$ is connected to four oxygen atoms in a square planar geometry, whereas $\mathrm{Cu}_{2} \mathrm{O}$ is linked with two oxygen atoms in a linear coordination. Therefore, the $\mathrm{Cu}(\mathrm{II})-\mathrm{O}$ bonds in $\mathrm{CuO}$ are weaker than $\mathrm{Cu}(\mathrm{I})-\mathrm{O}$ bonds and the vibration of the $\mathrm{Cu}-\mathrm{O}$ bond in $\mathrm{CuO}$ appears in lower frequencies than those that would be expected for $\mathrm{Cu}_{2} \mathrm{O}\left(625 \mathrm{~cm}^{-1}\right) .{ }^{33}$

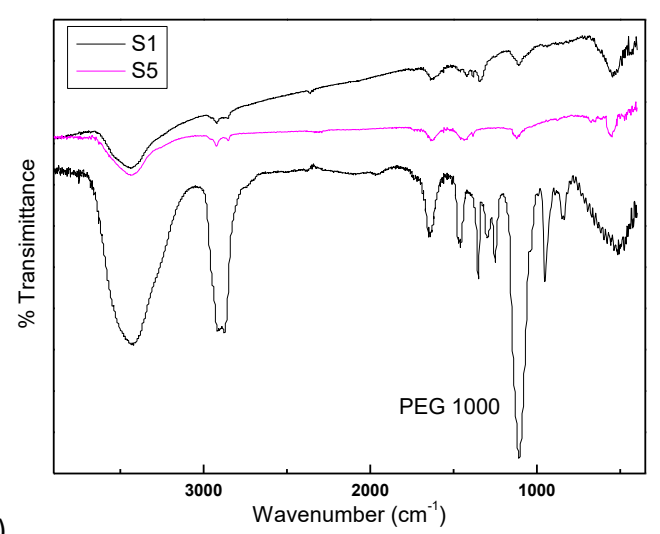

(a)

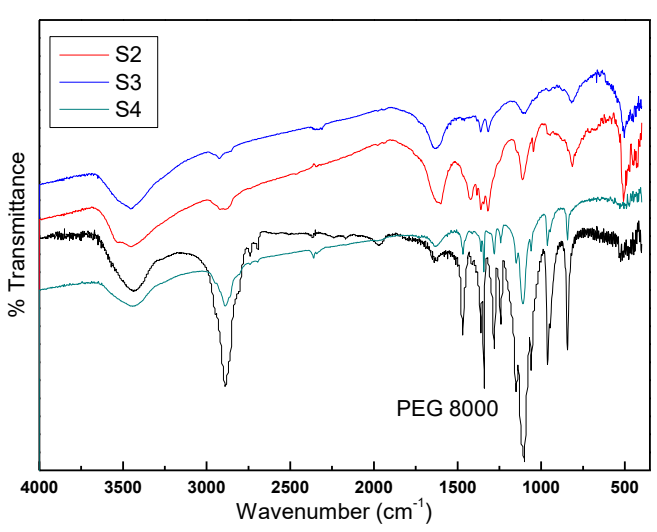


Figure 3. FTIR spectra of: (a) PEG 1000 and samples S1, S5 (b) PEG 8000 and samples $\mathrm{S} 2, \mathrm{~S} 3$ and $\mathrm{S} 4$.

The amount of organic coating on the surface of the nanoparticle was evaluated by thermogravimetric analysis (TGA) over a temperature rate up to $800{ }^{\circ} \mathrm{C}$ under nitrogen atmosphere and the curves are given in Figure 4 (a) and (b) for samples S1 and S5 and samples S2-S4 respectively. The decomposition temperature of all pure surfactants is in the vicinity of $400{ }^{\circ} \mathrm{C}$, while changes are attributed to the way of binding/adsorbing on the metal core. Similar thermal behavior occur to each set due to the same surfactant, while the cumulative organic content was estimated $33 \mathrm{wt} \%$ and $22 \mathrm{wt} \%$ for samples S1 and S5, respectively and $45 \mathrm{wt} \%, 39 \mathrm{wt} \%$ and $50 \mathrm{wt} \%$, for samples S2, S3 and S4 respectively. The decomposition of PEG 1000 occurs in either one (S1) or two steps (S5) up to $350{ }^{\circ} \mathrm{C}$, depending on the type of conformation, tight or loose, of the surfactant onto the nanoparticles. In case of samples S2 and S3 PEG 8000 was eliminated in three steps, while a different behavior was observed in the sample S4, where the decomposition occurs in four steps in a wider temperature range. Controversial explanations can be found in literature for decomposition in higher temperatures, since multi-stepped TGA curve is attributed to either a bi-layer formation of the organic coating ${ }^{34}$ or to two different kinds of binding sites. ${ }^{35}$

(a)



(b)

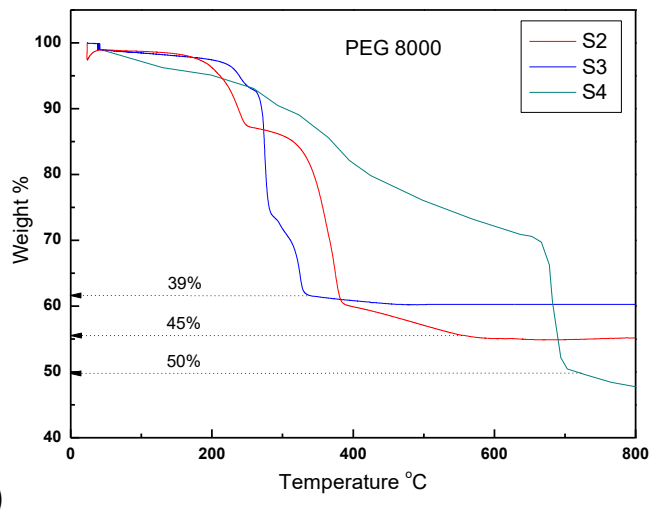


Figure 4. (a) Thermogravimetric curves of PEG 1000-capped (S1 and S5) and (b) PEG 8000- capped (S2, S3, S4) NPs under nitrogen flow with a temperature increase of 10 ${ }^{\circ} \mathrm{C} / \mathrm{min}$.

On the base of the obtained TGA results, the number of PEG molecules per one NP have been estimated. The calculations for samples S1-S5 were performed under assumption that the density of the nanoparticles $\left(6.5 \mathrm{~g} / \mathrm{cm}^{3}\right)$ is the same for the above samples and that their shape is totally spherical. ${ }^{36}$ As a result the number of ligands that are bound on the NPs was calculated (Eq. 1) and found 5693 and 3144 for S1 and S5, and 389, 133, 1024 ligands per particle for S2, S3 and S4, respectively.

$$
N=\frac{\omega N_{A} \rho \frac{4}{3} \pi R^{3} \times 10^{-23}}{M}
$$

Where $N$ is the number of ligands on each particle, $R$ is the mean radius of the $\mathrm{CuO}$ NPs, $\rho$ is the density of the NPs, $N_{\mathrm{A}}$ is Avogadro's number, $M$ is the molar mass of surfactant molecules $(\mathrm{g} / \mathrm{mol})$ and $\omega$ is the mass loss in percent $(\%)$.

In general, the biological activity of the NPs is strongly affected not only by their size and shape, but also by the conformation of PEG molecules on the surface of the NPs. Coating of NPs with PEG 1000 resulted in dramatic increase of hydrodynamic diameter of the NP (Table 1), while no significant increase of hydrodynamic diameter resulted in case of PEG 8000. This behavior is associated with the different grafting density of PEG 1000 and PEG 8000. In the latter case, the fewer PEG molecules may led in mushroom conformation, while in case of smaller MW as PEG 1000 brush conformation is expected, as reported also previously. ${ }^{37}$ Meanwhile, the conformation of PEG favors or not the ionic release from the NPs into the medium and affects the biological activity of NPs. ${ }^{13,38,39}$ Thus, CuO NPs have been incubated into PBS solution for $48 \mathrm{~h}$ in a rotary shaker and the ionic release has been measured (Table 1). 
Table 1. Summary of experimental results and main characteristics of samples S1-S5.

\begin{tabular}{|c|c|c|c|c|c|c|c|}
\hline Sample & Surfactant & $\begin{array}{l}\text { Temperature } \\
\left({ }^{\circ} \mathrm{C}\right)\end{array}$ & $\begin{array}{l}\text { Time } \\
\text { (h) }\end{array}$ & $\begin{array}{l}\text { Size by } \\
\text { XRD } \\
(n m)\end{array}$ & $\begin{array}{c}\text { Lattice } \\
\text { Parameters } \\
\alpha[\AA], \mathrm{b}[\AA], \mathrm{c}[\AA]\end{array}$ & $\begin{array}{l}\text { Mean size } \\
\text { in PBS } \\
(\mathrm{nm})\end{array}$ & $\begin{array}{c}\text { Ionic release per } \\
100 \mu \mathrm{g} / \mathrm{mL}\end{array}$ \\
\hline S1 & PEG1000 & 160 & 6 & 20 & $4.74,3.42,5.12$ & 998 & 2.108 \\
\hline S5 & PEG1000 & 160 & 8 & 18 & $4.74,3.42,5.13$ & 1120 & 3.44 \\
\hline $\mathrm{S} 2$ & PEG8000 & 150 & 12 & 15 & $4.68,3.42,5.13$ & 378 & 2.272 \\
\hline S3 & PEG8000 & 150 & 10 & 11 & $4.69,3.41,5.11$ & 389 & 0.832 \\
\hline S4 & PEG8000 & 150 & 8 & 20 & $4.72,3.42,5.12$ & 330 & 2.497 \\
\hline
\end{tabular}

Viability assays (MTT)

In order to investigate the potential use of the $\mathrm{CuO}$ NPs in cancer therapy, MTT assays were performed to evaluate how the PEGylated NPs of different sizes affect the viability of human cervical carcinoma (HeLa) cells by using human immortalized embryonic kidney (293 FT) cells as control cell line. Our data revealed that upon addition of low concentrations $(5-10 \mu \mathrm{g} / \mathrm{mL})$ of the NPs there is a significant decrease in viability of human cervical carcinoma, while NPs affected less the control cell line 293 FT (Figure 5). Higher concentrations of NPs $(25-100 \mu \mathrm{g} / \mathrm{mL})$ resulted in a more intense stimulus in cancer cell line as compared to the control. The HeLa cells appear more sensitive even at the lowest concentration tested $(5 \mu \mathrm{g} / \mathrm{mL})$. In the presence of CuO@PEG 1000 NPs of primary size $20 \mathrm{~nm}$ (sample S5) the cell viability was $63.5 \%$, whereas in 293 FT cells was $98.7 \%$ respectively. Furthermore, the observed viability for the concentration of $10 \mu \mathrm{g} / \mathrm{mL}$ differs significantly between the two cell lines. The higher difference was recorded in case of sample S2 (primary size $15 \mathrm{~nm}$ ). In that case, the cell viability in HeLa cells was reduced to $52.3 \%$, while the corresponding value in 293 FT cells was $86.6 \%$. 
By implementing ANOVA followed by Tukey, a comparison of the observed biological effects among the samples covered either with PEG 1000 or PEG 8000 was reported and the results did not record any statistical difference. The density and the molecular weight of PEG chain affected the stealth properties; the brush conformation may result to better flexibility of the NPs, while a mushroom regime could provide better protection of the metal core. ${ }^{18,19,37}$ It has to be mentioned that $\mathrm{CuO}$ NPs of primary size $11 \mathrm{~nm}$ (sample S3) could not distinguish between normal and cancerous cells. The $\mathrm{IC}_{50}$ value, which is defined as the lowest concentration of a compound or material that inhibits the $50 \%$ of the cell growth, ${ }^{7}$ was determined based on growth inhibition of cell cultures, containing varying concentration of the NPs in suspension. Upon the use of $11 \mathrm{~nm} \mathrm{CuO} \mathrm{NPs} \mathrm{the} \mathrm{IC}_{50}$ values recorded for $293 \mathrm{FT}$ and HeLa cells were 29.7 and $25.8 \mu \mathrm{g} / \mathrm{mL}$ respectively, attributed mainly to their smaller size (Table 2). Recently, the use of engineered nanoparticles for drug delivery in cancer therapy has been reviewed and the size of the NPs has been denoted as a crucial factor affecting the way of internalization inside the cells. In case of small nanoparticles $(<20 \mathrm{~nm})$ either pinocytosis or diffusion could occur instead of other selective endocytosis processes. ${ }^{36}$
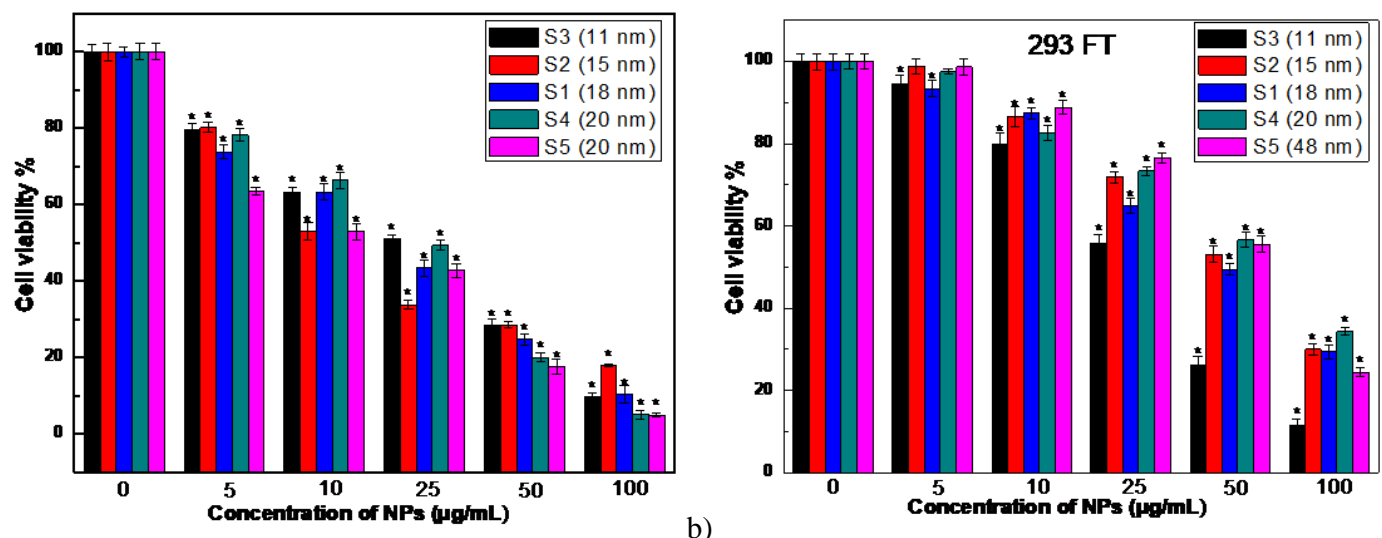

b)

Figure 5. MTT assay in (a) HeLa cell line and (b) 293 FT cells. Data represented are mean \pm SD of three identical experiments made in three replicates (asterisk denotes statistically significant difference from unexposed control, $\mathrm{p}<0.05)$. 
By comparing the $\mathrm{IC}_{50}$ values among the samples, a similar activity is exhibited, with the lowest value $(11.91 \mu \mathrm{g} / \mathrm{mL})$ in the cancer cell line being recorded in case of $\mathrm{CuO}$ NPs with primary and hydrodynamic size $20 \mathrm{~nm}$ and $1120 \mathrm{~nm}$, respectively. Those NPs released more ions in the medium $(3.44 \mu \mathrm{g} / \mathrm{mL})$ in comparison with the other samples and even though the value is relatively low, the ionic contribution to the activity of the NPs cannot be excluded. Similar value was reported $(\sim 14 \mu \mathrm{g} / \mathrm{mL})$ in a previous study of $30 \mathrm{~nm}$ "naked" CuO NPs towards MCF7 cells, ${ }^{16}$ while when 10 $\mu \mathrm{g} / \mathrm{mL}$ of $22 \mathrm{~nm}$ "naked" $\mathrm{CuO}$ NPs were applied to HepG2 cells, the cell viability decreased to $52 \% .{ }^{15}$ Although samples S2, S3, S4 have very similar hydrodynamic diameter, sample S3 has the smallest number of ligands per particle and exhibited the lowest $\mathrm{IC}_{50}(25.78 \mu \mathrm{g} / \mathrm{mL})$ towards the control cells 293FT. In that case the leaching of ions was found negligible $(0.832 \mu \mathrm{g} / \mathrm{mL})$ indicating that manner the close-packed conformation of the PEG molecules which resulted in better protection of the core. Thus, the activity arises mainly from the nanosized effect.

Table 2. Anticancer activity of $\mathrm{CuO}$ NPs evaluated by the half-minimal inhibitory concentration $\left(\mathrm{IC}_{50}\right)(\mu \mathrm{g} / \mathrm{mL})$.

\begin{tabular}{ccc}
\hline Sample & $\begin{array}{c}\mathrm{IC}_{50} \\
(\mu \mathrm{g} / \mathrm{mL}) \\
293 \mathrm{FT}\end{array}$ & $\begin{array}{c}\mathrm{IC}_{50} \\
(\mu \mathrm{g} / \mathrm{mL}) \\
\mathrm{HeLa}\end{array}$ \\
\hline S1 & 49.12 & 19.58 \\
S2 & 56.42 & 13.93 \\
S3 & 29.68 & 25.78 \\
S4 & 64.65 & 24.17 \\
S5 & 58.23 & 11.91 \\
\hline
\end{tabular}


Nitroblue Tetrazolium Assay (NBT)

The physicochemical characteristics of the NPs (composition, size, shape) ${ }^{37}$ as well as the characteristics of the NP target cell, i.e. the cell type,${ }^{38}$ affect their anticancer activity, since they interfere with their ability to selectively enter into the tumor cells. Apart from this fact, the cause of oxidative stress is also under investigation, since in previous study the biological activity of $\mathrm{CuO}$ NPs has been attributed mainly to ROS production. ${ }^{14}$ The results of the NBT assay demonstrate that the NPs induced oxidative stress in the HeLa cultures associated with the increase of $\mathrm{O}_{2}^{-}$in the cell cytoplasm (Figure 6) in agreement with previous studies. A significant dose-dependent response was observed in the assay for all the samples, while no significant differences among the samples are reported. In general, low concentrations stimulated the generation of $\mathrm{O}_{2}^{-}$with a moderate manner while a maximum stimulus in higher concentration tested $(50 \mu \mathrm{g} / \mathrm{mL})$ was found. This result supports that the anticancer activity of $\mathrm{CuO}$ NPs is mediated through oxidative stress. Previously it has been reported that CuO NPs can be the primary source of ROS if the release of $\mathrm{Cu}^{2+}$ ions is very low, ${ }^{13}$ as it happens in the present study. The strong adherence of the NPs to the cell membrane in combination with the production of ROS on the surface of the particles, cause an increase in cell permeability, leading to an uncontrolled transport of $\mathrm{CuO}$ NPs through the cytoplasmic membrane and ultimately to cell death. As mentioned previously, on the one hand ROS promote proliferation, angiogenesis and in that manner carcinogenesis; elevated ROS level activate constantly transcription factors. On the other hand, though, even higher level of ROS could become toxic to cell and cause apoptosis. ${ }^{39}$ 


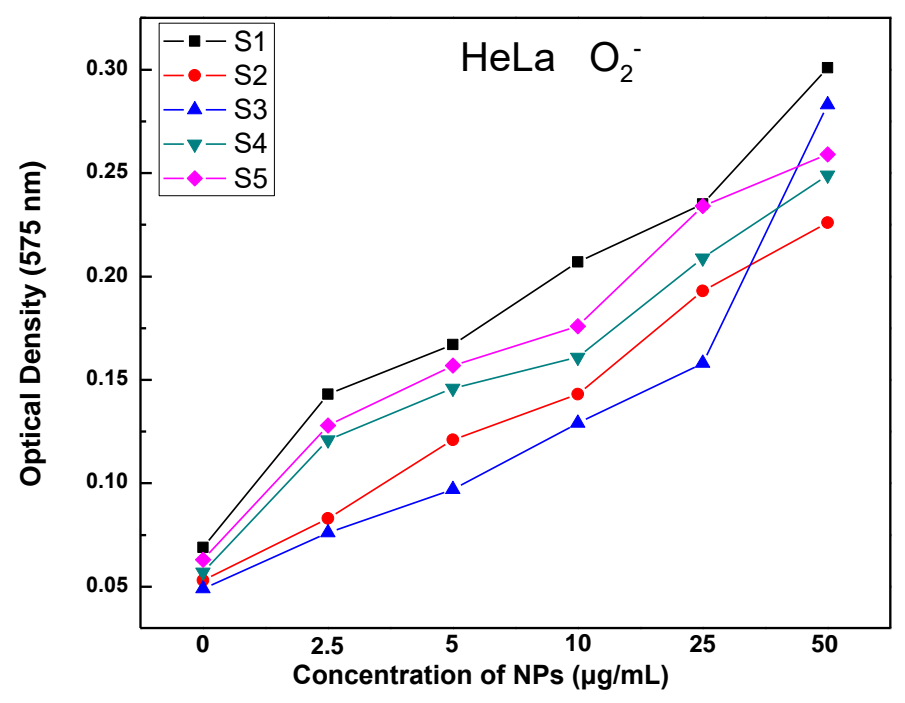

Figure 6. Intracellular $\mathrm{O}_{2}^{-}$generated by $\mathrm{CuO}$ NPs (samples S1-S5) in HeLa cell line detected by nitroblue tetrazolium assay.

\section{Lactate Dehydrogenase assay (LDH)}

The amount of $\mathrm{LDH}$ of the cells after $24 \mathrm{~h}$ of incubation in the presence of the NPs was also estimated. All samples induced apparent LDH leakage from HeLa cells treated for $24 \mathrm{~h}$, which revealed the impact of nanoparticles on cell membrane integrity (Figure 7). LDH levels in cell medium were low up to the concentration of $10 \mu \mathrm{g} / \mathrm{mL}$, whereas at the higher doses the LDH levels were elevated rapidly. The results are in accordance with those of the MTT and NBT assays, as a general trend. The biggest in terms of hydrodynamic and primary size $\mathrm{CuO}$ NPs cause the highest release of LDH, suggesting physical damage on the cellular membrane rather than solely crossing through the cell membrane and entering the cytoplasm. In the smaller $\mathrm{CuO}$ NPs membrane damage is exerted mainly via ROS generation as indicated by NBT assay and not through direct contact. The direct contribution of ions released to the medium or via ROS produced by ions cannot be excluded. 


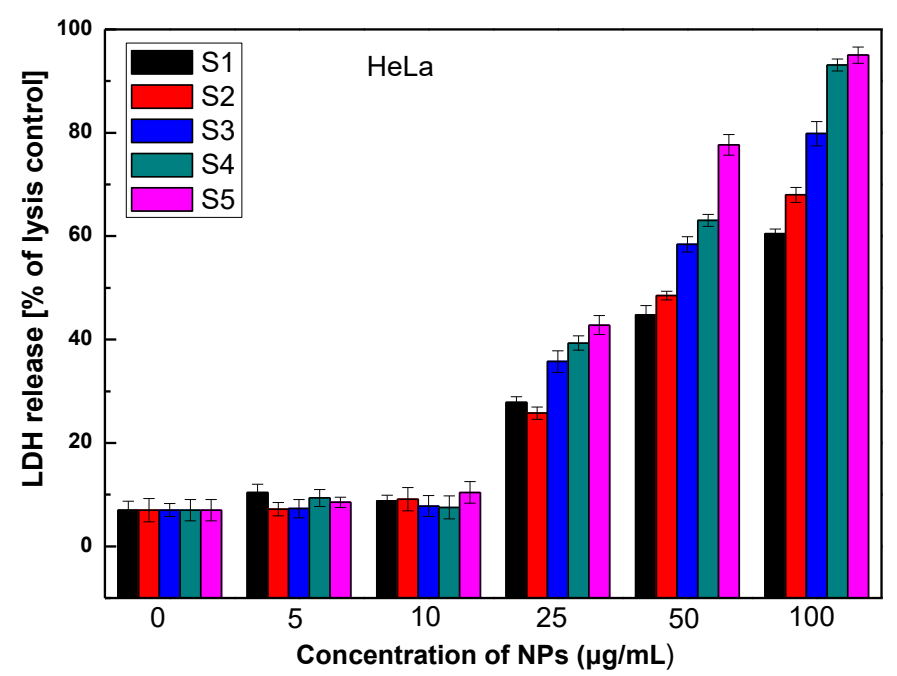

Figure 7. LDH leakage from HeLa cells after $24 \mathrm{~h}$ treatment with samples S1-S5. Cells were respectively treated with $5,10,25,50$ and $100 \mu \mathrm{g} \mathrm{ml}^{-1}$ of $\mathrm{CuO}$ NPs for $24 \mathrm{~h}$. Results are the mean \pm SD of three independent experiments each carried out in triplicate. Statistically significant difference as compared to the controls $(\mathrm{p}<0.05$ for each).

DNA degradation after exposure to NPs in agarose gel electrophoresis

The effect of the NPs on DNA isolated from HeLa cells treated for $24 \mathrm{~h}$ at 37 ${ }^{\circ} \mathrm{C}$ with 10 and $100 \mu \mathrm{g} / \mathrm{mL}$ of samples $\mathrm{S} 1-\mathrm{S} 5$ was studied. A representative electrophoretic pattern of agarose gel electrophoresis is shown in Figure 8. DNA isolated from untreated cells exhibit one major characteristic band of unaffected/intact chromosomal DNA (Lane C: control), while DNA isolated from cells treated with the NPs exhibit several bands almost equally distant revealing degradation of nucleosomes, a very characteristic pattern similar to a ladder or apoptotic DNA laddering due to cleavage of chromatin DNA into internucleosomal fragments of roughly 180 base pairs (bp) and multiples thereof (360, 540 etc.). Because DNA portions of nucleosome core particles are less accessible for NPs than linking sections, DNA gets digested into 
fragments of lengths equal to multiplicity of distance between nucleosomes. This result indicates that the NPs either managed to enter the cells and to assault directly nuclear DNA by mimicking or by inducing endonuclease activity or ROS production and ionic release took place which affected indirectly the DNA integrity.

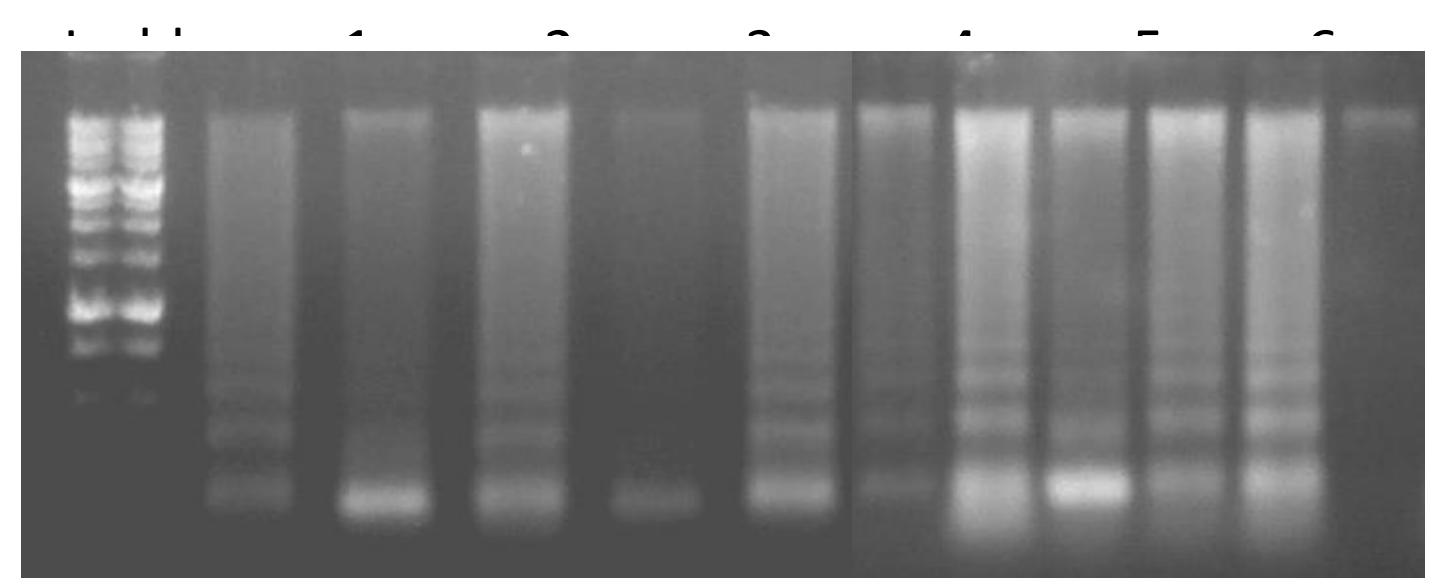

Figure 8. Dose-dependent DNA degradation action of the NPs in agarose gel electrophoresis. Lane C: DNA without treatment with NPs (control); Lanes 1-2: DNA treated with 10 and $100 \mu \mathrm{g} / \mathrm{mL}$ of 15 nm CuO@PEG8000 NPs (S2); Lanes 3-4: DNA treated with 10 and $100 \mu \mathrm{g} / \mathrm{mL}$ of 18 nm CuO@PEG1000 NPs (S5); Lanes 5-6: 10 and $100 \mu \mathrm{g} / \mathrm{mL}$ of $20 \mathrm{~nm} \mathrm{CuO} @$ PEG8000 NPs (S1); Lanes 7-8: DNA treated with 10 and $100 \mu \mathrm{g} / \mathrm{mL}$ of $11 \mathrm{~nm} \mathrm{CuO@PEG8000} \mathrm{NPs} \mathrm{(S3);} \mathrm{Lanes} \mathrm{9-10:} \mathrm{DNA} \mathrm{treated} \mathrm{with} 10$ and $100 \mu \mathrm{g} / \mathrm{mL}$ of $20 \mathrm{~nm}$ CuO@PEG8000 NPs (S4). As DNA markers the $1 \mathrm{~kb}$ ladder was used.

DNA isolated from HeLa cells treated for $24 \mathrm{~h}$ at $37{ }^{\circ} \mathrm{C}$ with $10 \mu \mathrm{g} / \mathrm{mL}$ of 15 nm CuO@PEG8000 NPs or 20 nm CuO@PEG1000 NPs (Lanes 1,3 Figure 8) has been degraded, since bands of lower molecular weights appeared in the gel. The higher concentration $(100 \mu \mathrm{g} / \mathrm{mL})$ in the first case resulted in significant degradation effect, while in the latter case complete degradation of the DNA (lane 4) was observed. The DNA integrity was also affected in the presence of 18 nm CuO@PEG1000 NPs (lanes 
5,6), of $11 \mathrm{~nm}$ (lanes 7,8) and $20 \mathrm{~nm}$ (lanes 9,10) CuO@PEG8000 NPs as indicated by the DNA fragmentation observed in all cases. DNA fragmentation can be considered as one of the biomarkers that characterize apoptosis. ${ }^{40}$ By taking into account the DNA interaction could be achieved either directly or indirectly, the size of the nanoparticles (hydrodynamic and/or primary) becomes the crucial factor that determines whether the NPs enter into the cytoplasm and the nucleus. The hydrodynamic size of the NPs was determined in PBS $(\mathrm{pH}=7.2)$. However, we have to take into account that the acidic conditions of tumors favor the dissolution of NPs and thus NPs could enter selectively on cancer cells and interact directly with subcellular organelles. ${ }^{41}$ The smaller NPs (primary size 11-20 nm) could direct interact with the DNA, ${ }^{42}$ while an indirect effect on DNA through the production of ROS is supported by the bigger sizes. ${ }^{43}$ However, the latter mechanism of action or synergistic effects cannot be excluded also for the smaller NPs.

In vitro inhibition of soybean lipoxygenase (LOX)

It is generally accepted that there is a close association between cancer and inflammation. ${ }^{44}$ Therefore, oxidative enzymes that are known to play a key role in inflammation are increasingly investigated in connection to cancer. Lipoxygenases are a group of oxidative enzymes with a non-heme iron atom in their active site, which are involved in the regulation of inflammatory responses through catalyzing the insertion of oxygen $\left(\mathrm{O}_{2}\right)$ into poly-unsaturated fatty acids such as arachidonic acid and linoleic acid. In the catalytic reaction, $\mathrm{Fe}^{3+}$ is reduced to $\mathrm{Fe}^{2+}$ with concomitant oxidation of the lipid substrate by hydrogen abstraction from a bis-allylic methylene to give a pentadienyl radical, which is re-arranged to provide a 1-cis,3-trans-conjugated diene 
moiety. Subsequently, a stereo-specific insertion of oxygen at the pentadienyl radical takes place to form an oxygen-centered fatty acid hydroperoxide radical, which are mediators of inflammation. ${ }^{45}$

Generation of ROS, rapid LDH release indicative of membrane damage and DNA damage were reported and are the main factors affecting the mechanism of action of the NPs. In a previous study, lipoxygenase inhibitors induced apoptosis in breast cancer cells in vitro. ${ }^{46}$ Thus, to account for the anti-inflammatory activity of the $\mathrm{CuO}$ NPs, the inhibitory effect on the lipoxygenase enzyme activity was investigated. In all cases, enzyme inhibition is observed in a concentration-dependent manner, while the $\mathrm{IC}_{50}$ values did not differ significantly among the samples (Table 3 ). Figure $8 \mathrm{a}$ and $8 \mathrm{~b}$ shows indicative curves of samples S4 and S5, respectively, exhibiting high LOX inhibition with the half maximal inhibitory concentration $\left(\mathrm{IC}_{50}\right)$ values being 4 and 4.5 $\mu \mathrm{g} / \mathrm{mL}$, respectively (Table 3). The enhanced activity of the CuO NPs as compared to the control naproxen $(5.5 \mu \mathrm{g} / \mathrm{mL})$ could be attributed to their smaller size, which probably allows for closer interaction with the LOX enzyme.
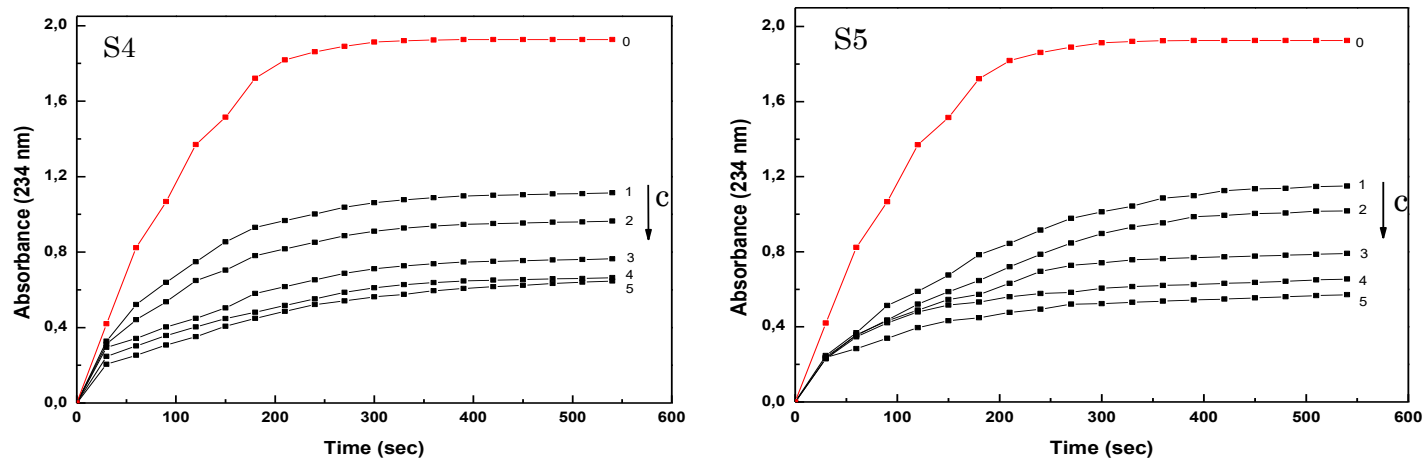

Figure 9. LOX inhibition in (a) sample S4 and (b) sample S5 upon increasing concentrations (1: $2.5 \mu \mathrm{g} / \mathrm{mL}, 2: 5 \mu \mathrm{g} / \mathrm{mL}, 3: 10 \mu \mathrm{g} / \mathrm{mL}, 4: 25 \mu \mathrm{g} / \mathrm{mL}$ and 5: $50 \mu \mathrm{g} / \mathrm{mL}$ ).

Table 3. Anti-inflammatory activity of $\mathrm{CuO}$ NPs evaluated by the half-minimal inhibitory concentration $\left(\mathrm{IC}_{50}\right)(\mu \mathrm{g} / \mathrm{mL})$. 


\begin{tabular}{cc}
\hline Samples & $\begin{array}{c}\text { LOX Inhibition } \\
\mathrm{IC}_{50}(\mu \mathrm{g} / \mathrm{mL})\end{array}$ \\
\hline S1 & 5.9 \\
S2 & 4.8 \\
S3 & 5.3 \\
S4 & 4 \\
S5 & 4.5 \\
\hline
\end{tabular}

\section{Conclusions}

PEGylated $\mathrm{CuO}$ NPs in a range of sizes (11-20 nm) were synthesized by varying the reaction time upon properly adjusting the temperature and $\mathrm{pH}$. PEGylation offers not only high colloidal stability, but also protein resistance allowing for selective detection of biological targets due to their stealth characteristics. The results concerning the anticancer activity of the NPs indicated a trend of differential viability between HeLa cells and 293 FT cells, while a concentration-dependent behavior in all cases was also demonstrated. The NPs exhibited enhanced selectivity that led to selective apoptosis of tumor cells through DNA damage and ROS generation, and/or by causing membrane damage through direct physical contact. The in vitro anti-inflammatory activity was evidenced as the $\mathrm{CuO}$ NPs inhibited efficiently the lipoxygenase enzyme. These promising results enable for extension of the studies to different cancer cell lines in accordance with in vivo studies, while further functionalization of the NPs with magnetic nanoparticles could improve also their targeted biological activity. PEG molecules have the potential to become multifunctional upon combining with fluorescent agents or other functional groups, while can be used as a matrix for drug loading, as previously reported by us. ${ }^{47}$ In this respect, PEGylation chemistry can be 
extended as an inherent part of the therapeutic, diagnostic, and imaging platform in addition to the passive coating for the repulsion of opsonin proteins.

\section{Abbreviations}

NPs

PEG 1000

PEG 8000

$\mathrm{Cu} \mathrm{NPs}$

$\mathrm{CuO}$

HepG2

MTT

ROS

NBT

TGA

TEM

DLS

LDH

LOX

$\mathrm{MIC}\left(\mathrm{IC}_{50}\right)$

EPR

RES

HeLa

Eth $\mathrm{Br}$

DMEM

SDS

EDTA

293FT
Nanoparticles

polyethylene glycol 1000

polyethylene glycol 8000

Copper nanoparticles

cupric oxide

human hepatocellular carcinoma cells

3-(4,5-dimethylthiazol-2-yl)-2,5-

diphenyltetrazolium bromide

reactive oxygen species

Nitroblue Tetrazolium

Thermogravimetric analysis

Transmission Electron Microscopy

Dynamic Light Scattering

lactate dehydrogenase

Lipoxygenase

Minimum Inhibitory Concentration

Enhanced permeation and retention

reticulo-endothelial system

human cervical carcinoma

ethidium bromide

Dulbecco's modified Eagle's medium

with L-glutamine

Sodium Dodecyl Sulfate

ethylenediaminetetraacetic acid

human immortalized embryonic kidney 


\section{References list}

${ }^{1}$ Marzano, C., Pellei, M., Tisato, F., Santini, C. Copper complexes as anticancer agents. Anti-Cancer Agents in Medicinal Chemistry, 2009, 9, 185-211.

2 Sun, T., Zhang, Y.S., Pang, B., Hyun, D.C., Yang, M., Xia, Y. Engineered nanoparticles for drug delivery in cancer therapy. Angew. Chem. Int. Ed. 2014, 53, $12320-12364$.

${ }^{3}$ Arora, S., Rajwade, J.M., Paknikar, K.M. Nanotoxicology and in vitro studies: the need of the hour. Toxicology and Applied Pharmacology 2012, 258, 151-165.

${ }^{4}$ AshaRani, P.V., Kah Mun, G.L., Hande, M.P., Valiyaveettil, S. Cytotoxicity and genotoxicity of silver nanoparticles in human cells. ACS Nano, 2009, 3, 279-290.

${ }^{5}$ Wang, H., Zi, X.-Y., Su, J. et al. Cuprous oxide nanoparticles selectively induce apoptosis of tumor cells. Int. J. Nanomed. 2012, 7, 2641-2652.

${ }^{6}$ Xu, M., Fujita, D., Kajiwara, S., Minowa, T., Li, X., Takemura, T., Iwai, H., Hanagata, N. Contribution of physicochemical characteristics of nano-oxides to cytotoxicity. Biomaterials 2010, 31, 8022-8031.

${ }^{7}$ Suresh, A.K., Pelletier, D.A., Doktycz, M.J. Relating nanomaterial properties and microbial toxicity. Nanoscale, 2013, 5, 463-474.

${ }^{8}$ Giannousi, K., Avramidis, I., Dendrinou-Samara, C. Synthesis, characterization and evaluation of copper based nanoparticles as agrochemicals against Phytophthora infestans. RSC Adv. 2013, 3, 21743-21752.

${ }^{9}$ Giannousi, K., Lafazanis, K., Arvanitidis, J., Pantazaki, A., Dendrinou-Samara, C. Hydrothermal synthesis of copper based nanoparticles: Antimicrobial screening and interaction with DNA. J. Inorg. Biochem. 2014, 133, 24-32. 
${ }^{10}$ Giannousi, K., Sarafidis, G., Mourdikoudis, S., Pantazaki, A., Dendrinou-Samara, C. Selective Synthesis of $\mathrm{Cu}_{2} \mathrm{O}$ and $\mathrm{Cu} / \mathrm{Cu}_{2} \mathrm{O}$ NPs: Antifungal Activity to Yeast Saccharomyces cerevisiae and DNA Interaction. Inorg. Chem. 2014, 53, 9657-9666.

${ }^{11}$ Azam, A., Ahmed, A.S., Oves, M., Khan, M.S., Adnan Memic, Size-dependent antimicrobial properties of $\mathrm{CuO}$ nanoparticles against Gram-positive and -negative bacterial strains. Int. J. Nanomed. 2012, 7, 3527-3535.

${ }^{12}$ Chang, Y.-N., Zhang, M., Xia, L., Zhang, J., Xing, G. The Toxic Effects and Mechanisms of $\mathrm{CuO}$ and $\mathrm{ZnO}$ Nanoparticles. Materials, 2012, 5, 2850-2871.

${ }^{13}$ Applerot, G., Lellouche, J., Lipovsk, A., Nitzan, Y., Lubart, R., Gedanken, A., Banin, E. Understanding the antibacterial mechanism of $\mathrm{CuO}$ nanoparticles: revealing the route of induced oxidative stress. Small 2012, 8, 3326-3337.

${ }^{14}$ Meghana, S., Kabra, P., Chakraborty, S., Padmavathy, N. Understanding the pathway of antibacterial activity of copper oxide nanoparticles. RSC Adv. 2015, 5, 12293-12299. 15 Siddiqui, M.A, Alhadlaq, H.A., Ahmad, J., Al-Khedhairy, A.A., Musarrat, J., Ahamed, M. Copper Oxide Nanoparticles Induced Mitochondria Mediated Apoptosis in Human Hepatocarcinoma Cells. PLOS ONE, 2013, 8, e69534.

${ }^{16}$ Laha, D., Pramanik, A., Maity, J. et al. Interplay between autophagy and apoptosis mediated by copper oxide nanoparticles in human breast cancer cells MCF7. Biochimica et Biophysica Acta 2014, 1840, 1-9.

${ }^{17}$ Laurent, A., Nicco, C., Chereau, C. et al. Controlling tumor growth by modulating endogenous production of reactive oxygen species. Cancer Res 2005, 65, 948-956.

${ }^{18}$ Karakoti, A.S., Das, S., Thevuthasan, S., Seal, S. PEGylated Inorganic Nanoparticles. Angew. Chem. Int. Ed. 2011, 50, 1980 - 1994.

${ }^{19}$ Jokerst, J.V., Lobovkina, T., Zare, R.N., Gambhir, S.S. Nanoparticle PEGylation for imaging and therapy. Nanomedicine 2011, 6, 715-728. 
20 Ananth, A., Dharaneedharan, S., Heo, M.-S., Sun Mok, Y. Copper oxide nanomaterials: Synthesis, characterization and structure-specific antibacterial performance. Chemical Engineering Journal 2015, 262, 179-188.

21 Wisastra, R., Dekker, F.J. Inflammation, Cancer and Oxidative Lipoxygenase Activity are Intimately Linked. Cancers 2014, 6, 1500-1521.

${ }^{22}$ Ulmer, D.D., Vallee, B.L., Wacker, W.E. Metalloenzymes and myocardial infarction. II. Malic and lactic dehydrogenase activities and zinc concentrations in serum. N. Engl. J. Med. 1956, 255, 450-456.

${ }^{23}$ Becerra, M.C., Eraso, A.J., Albesa, I. Comparison of oxidative stress induced by ciprofloxacin and pyoverdin in bacteria and in leukocytes to evaluate toxicity. Luminescence 2003, 18, 334-340.

${ }^{24}$ Harju, S., Fedosyuk, H., Peterson, K.R. Rapid isolation of yeast genomic DNA: Bust n' Grab. BMC Biotechnol. 2004, 4, doi:10.1186/1472-6750-4-8.

${ }^{25}$ Herrmann, M., Lorenz, H.M., Voll, R., Grunke, M., Woith, W., Kalden, J.R. A rapid and simple method for the isolation of apoptotic DNA fragments. Nucleic Acids Research 1994, 22, 5506-5507.

${ }^{26}$ Shahmiri, M., Ibrahim, N.A., Zainuddin, N., Asim, N., Bakhtyar, B., Zaharim, A., Sopian, K. Effect of $\mathrm{pH}$ on the synthesis of $\mathrm{CuO}$ nanosheets by quick precipitation method. WSEAS Transactions on Environment and Development, 2013, 9, 137-146.

27 Gilbert, B., Ono, R.K., Ching, K.A., Kim, C.S. The effects of nanoparticle aggregation processes on aggregate structure and metal uptake. Journal of Colloid and Interface Science, 2009, 339, 285-295.

${ }^{28}$ Sun, M., Zhu, A., Zhang, Q., Liu, Q. A facile strategy to synthesize mono disperse super paramagnetic OA-modified Fe3O4 nanoparticles with PEG assistant. J. Magn. Mater. 2014, 369, 49-54. 
${ }^{29}$ Chen, K., Xue, D. pH-assisted crystallization of $\mathrm{Cu} 2 \mathrm{O}$ : chemical reactions control the evolution from nanowires to polyhedra. CrystEngComm 2012, 14, 8068-8075.

${ }^{30}$ Huang, C.C., Hwu, J.R., Su, W.C., Shieh, D.B., Tzeng, Y., Yeh, C.S. SurfactantAssisted Hollowing of $\mathrm{Cu}$ Nanopaticles Incorporating with Halide-Induced Corrosion Oxidation. Chem. Eur. J. 2006, 12, 3805-3810.

${ }^{31}$ Krishnan, S., Haseeb, A.S.M.A., Johan, M.R. Synthesis and growth kinetics of spindly $\mathrm{CuO}$ nanocrystals via pulsed wire explosion in liquid medium. J. Nanopart. Res. 2013, 15, 1410-1419.

${ }^{32}$ Park Y., Whitaker R.D., Nap R.J., Paulsen J.L., Mathiyazhagan V., Doerrer L.H., Song Y.Q., Hürlimann M.D., Szleifer I. and Wong J.Y. Stability of superparamagnetic iron oxide nanoparticles at different $\mathrm{pH}$ values: experimental and theoretical analysis. Langmuir, 2012, 28, 6246-6255.

${ }^{33}$ Zhang, Y.C., Tang, J.Y., Wang, G.L., Zhang, M., Hu, X.Y. Facile synthesis of submicron $\mathrm{Cu} 2 \mathrm{O}$ and $\mathrm{CuO}$ crystallites from a solid metallorganic molecular precursor. J. Cryst. Growth, 2006, 294, 278-282.

${ }^{34}$ Shen, L., Laibinis, P. E., Hatton, T.A. Bilayer Surfactant Stabilized Magnetic Fluids: Synthesis and Interactions at Interfaces. Langmuir 1999, 15, 447-453.

${ }^{35}$ Bastami, T.R., Entezari, M.H., Hua, Q.H., Hartono, S.B., Qia, S.Z. Role of polymeric surfactants on the growth of manganese ferrite nanoparticles. Chemical Engineering Journal 2012, 210, 157-165.

${ }^{36} \mathrm{Mu}$, Q., Jiang, G., Chen, L. et al. Chemical Basis of Interactions Between Engineered Nanoparticles and Biological Systems. Chem. Rev. 2014, 114 (15), 7740-7781. 
${ }^{37}$ Unfried, K., Albrecht, C., Klotz, L.-O., von Mikecz, A., Grether-Beck, S., Schins, R.P.F. Cellular responses to nanoparticles: Target structures and mechanisms. Nanotoxicology, 2007, 1, 52-71.

${ }^{38}$ Sohaebuddin, S.K., Thevenot, P.T., Baker, D., Eaton, J.W., Tang, L. Nanomaterial cytotoxicity is composition, size, and cell type dependent. Part Fibre Toxicol. 2010, 7, 22.

${ }^{39}$ Szatrowski, T.P., and Nathan, C.F. Production of large amounts of hydrogen peroxide by human tumor cells. Cancer Res. 1991, 51, 794-798.

${ }^{40}$ Kroemer, G, Petit P, Zamzami, N, Vayssiere, J.L., Mignotte, B. The biochemistry of programmed cell death. FASEB J. 1995, 9, 1277-1287.

${ }^{41}$ Lee, I.-C., Ko, J.-W. et. al. Comparative toxicity and biodistribution of copper nanoparticles and cupric ions in rats. International Journal of Nanomedicine 2016, 11, 2883-2900

${ }^{42}$ Chen, M., Mikecz, A. Formation of nucleoplasmic protein aggregates impairs nuclear function in response to $\mathrm{SiO} 2$ nanoparticles. Exp Cell Res. 2005,305, 1, 51-62.

43 Alomar, S. Cadmium sulfide nanoparticle induces oxidative stress and proinflammatory effects in human lung adenocarcinoma epithelial cells. Toxicol Environ Chem. 2015, 97, 5,619-633.

${ }^{44}$ Nowsheen, K., Aziz, T.B., Kryston, N.F., Ferguson, N.F., Georgakilas, A. The interplay between inflammation and oxidative stress in carcinogenesis. Curr. Mol. Med. 2012, 12, 672-680.

45 Guo, C., Nie, D. Are Lipoxygenases Valid Targets of Cancer Prevention and Treatment? J. Carcinogen. Mutagen. 2012, S1, http://dx.doi.org/4172/2157-2518.S1008. 
${ }^{46}$ Tong, W.G., Ding, X.Z., Adrian, T.E. The mechanisms of lipoxygenase inhibitorinduced apoptosis in human breast cancer cells. Biochem. Biophys. Res. Commun. 2002, 296, 942-948.

${ }^{47}$ Georgiadou, V., Makris, G., Papagiannopoulou, D., Vourlias, G. and DendrinouSamara C. Octadecylamine Mediated Versatile Coating of $\mathrm{CoFe}_{2} \mathrm{O}_{4}$ NPs for the Sustained Release of Anti-inflammatory Drug Naproxen and in vivo Target Selectivity ACS Applied Materials and Interfaces 2016, 8 14, 9345-9360. 